\begin{tabular}{|c|c|c|}
\hline institute & $\begin{array}{l}\text { CARADDE: Jurnal Pengabdian Kepada Masyarakat } \\
\text { https://journal.ilininstitute.com/index.php/caradde } \\
\text { Volume 1 | Nomor 2 | Februari | 2019 } \\
\text { e-ISSN: } 2621-7910 \text { dan p-ISSN: 2621-7961 } \\
\text { DOI: https://doi.org/10.31960/caradde.v1i2.63 }\end{array}$ & $\begin{array}{l}\text { EIIN } \\
\text { garaddE }\end{array}$ \\
\hline
\end{tabular}

\title{
Achievement Motivation Counseling Untuk Meningkatkan Kinerja Difabel Dalam Usaha Tata Rias Salon Di Kabupaten Tegal
}

\author{
Sri Adi Nurhayati ${ }^{1}$, Sesya Dias Mumpuni ${ }^{2}$
}

\begin{tabular}{ll}
\hline \hline Keywords : & Abstrak. Tujuan dari pengabdian kepada masyarakat ini \\
Bimbingan dan konseling; & adalah memberikan motivasi untuk meningkatkan kinerja \\
Disabilitas; & difabel pada pekerjaan menjahit dan tata rias untuk menuju \\
Pemberdayaan. & $\begin{array}{l}\text { Msaha tata rias salon. Pentingnya memberikan Achievement } \\
\text { Motivation Counseling sebagai dasar penguatan difabel akan }\end{array}$ \\
Corespondensi Author & usaha yang dirintis dan diteruskan untuk selanjutnya. Metode \\
Bimbingan dan Konseling, & yang digunakan dalam pelaksanaan pengabdian kepada \\
Universitas Pancasakti Tegal & masyarakat ini terdiri dari pelatihan, workshop dan \\
J1. Halmahera Km 1 Kota Tegal & Achievement Motivation Counseling. Hasil dari pelatihan \\
Email: & berupa keterampilan dalam baju kebaya, tata rias salon dan \\
wondermomson@gmail.com ${ }^{1}$, & motivasi diri difabel untuk memulai usaha. Simpulan dari \\
dias.mumpuni@live.com ${ }^{2}$ & pengabdian kepada masyarakat ini adalah mitra difabel \\
& memperoleh keterampilan yang baik dalam usaha tata rias \\
History Artikel & salon yang dilakukan dalam bentuk busana kebaya, tata rias \\
Received: Desember-2018; & dan motivasi diri dalam berusaha.
\end{tabular}

Reviewed: Desember-2018

Accepted: Februari-2018

Published: Februari-2019 (i) This work is licensed under a Creative Commons Attribution

4.0 International License

\section{PENDAHULUAN}

Konseling merupakan cara pemberian bantuan psikis kepada seseorang yang sedang mengalami kondisi ketidakefektifan kehidupan sehari-hari. Hal ini tentu saja dialami oleh orang pada umumnya dan difabel. Difabel pada lingkungan di sekitar kita masih merupakan hal yang belum dapat diterima seutuhnya. Kondisi ini diperparah dengan istilah yang digunakan dalam penyebutan difabel yang masih mengunakan subjek orang cacat. Penggunaan istilah bagi penyandang disabilitas menurut ILO (2015: 9) menggunakan istilah "disabled person" dan "person with disability" dan bentuk jamaknya dapat digunakan bergantian untuk menunjukkan berbagai penggunaan istilah ini di seluruh dunia.
Dalam penggunaan istilah yang digunakan dalam penyebutan difabel ILO juga menerangkan bahwa di beberapa negara, penggunaan istilah yang mengedepankan orang yang bersangkutan sangat disarankan, misalnya istilah "orang dengan disabilitas" atau "orang dengan disabilitas intelektual" dan dianggap sebagai yang paling sopan. Penting juga merujuk penyandang disabilitas dengan istilah yang paling sopan di negara atau budaya Anda serta menggunakan kalimat yang dipilih oleh penyandang disabilitas sendiri (ILO, 2015: 9).

Konseling bagi difabel sama halnya kepada masyarakat pada umumnya. Hanya perlu di Bahkan kesetaraan seluruh umat manusia diuji dengan adanya orang-orang difabel. Tidak ada manusia yang sempurna, maka kita terhadap orang lain setidaknya 
dapat bersikap saling memahami kondisi difabel dengan segala keterbatasannya. Dalam menjalani hidup difabel sangat berat, misalnya dalam menerima kondisi diri. Beberapa difabel yang telah bangkit dari peimikiran bahwa difabel tidak bisa apa-apa. Namun ada beberapa difabel yang belum dapat menerima diri sehingga dalam melanjutkan hidupnya seperti sekolah dan bekerja belum dapat terpenuhi. Menurut WHO dalam Indonesian Journal of Disability Studies (Sugiono dkk: 2014) mengenai konsep difabel yaitu 'disable' tidak ada kaitannya dengan fisik. Difabel lebih ditekankan pada kegagalan dalam berorganisasi sosial dalam memperhitungkan kebutuhan yang berlainan antara kaum difabel dengan kaum normal dan menghilangkan batasan di antara keduanya.

Menurut data BPS Kabupaten Tegal 2015 jumlah difabel yang ada di Kabupaten Tegal tidak sedikit yaitu total 6.805 jiwa difabel termasuk difabel anak. Jumlah difabel dewasa 5.027 jiwa yang dalam kategori BPS Kabupaten Tegal. Difabel menggunakan fasilitas umum sama dengan manusia normal yang lain. Maka perlu adanya ketersediaan sarana dan prasarana yang mampu menunjang difabel untuk mengakses layanan tersebut. Pada Peraturan Pemerintah Nomor 43 tahun 1998 tentang Upaya Peningkatan Kesejahteraan Sosial Penyandang Cacat (bphn.2018) adanya dasar untuk memberikan pemberdayaan bagi difabel. Upaya peningkatan kesejahteraan bagi difabel yang bertujuan untuk kemandirian dan kesejahteraan kepada difabel.

Perlu adanya penanganan bersama untuk dapat membantu difabel agar kehidupannya lebih baik. Salah satunya dengan memberikan dorongan kepada difabel untuk bekerja sesuai dengan keterampilan dan kemampuan yang dimiliki. Berbagai keterampilan dapat dilakukan difabel pada lingkungan yang mendukung seperti pada komunitas difabel yang ada di Kabupaten Tegal yaitu Difabel Slawi Mandiri (DSM) dan Loka Bina Karya (LBK) Kabupaten Tegal. Covey (2015:34) "Beberapa dari tulisan ini mengakui karakter sebagai bahan baku kesuksesan, tapi cenderung mengkotak-kotakannya, dan bukan mengakuinya sebagai landasan dan katalis". Komunitas yang berbadan hukum ini telah memulai memberdayakan difabel dalam berbagai kegiatan di masyarakat.
Dengan adanya Undang-undang Nomor 8 Tahun 2016 tentang Penyandang Disabilitas, menegaskan bahwa difabel merupakan bagian masyarakat yang mempunyai hak dan kesempatan yang sama dalam segala aspek kehidupan dan penghidupan khususnya dalam bekerja. Menurut Cornish et all (2010: 56) difabel yaitu "Marks further states that the definition of disability is associated with a conglomerate of theories regarding the body, society, and psyche. The lack of consensus regarding the definition of disability is observed throughout the literature." Memahami difabel tidak mudah, namun kita semua dapat melakukan itu. Permasalahan yang sering muncul bahwa masyarakat yang mengganggap difabel secara fisik tidak mampu bekerja sangat memberikan efek yang luar biasa pada diri difabel. Produktifitas difabel tidak kalah dengan orang lain yang bekerja. Ketika kondisi ini mampu dipahami oleh diri difabel, maka kesempatan untuk berjuang dalam kehidupan khususnya dalam bekerja sangat terbuka lebar.

Kinerja difabel dalam bekerja yang ditemui pada komunitas DSM Kabupaten Tegal sangat beragam. Pineida (2011) menjelaskan "A learning competency is a human ability that facilitates learning". Ada beberapa keterampilan kerja yang nantinya akan mendorong kinerja difabel. Keterampilan pekerjaan yang telah dilakukan antara lain menjahit, budidaya jamur tiram, membuat kue kecil dan pementasan drama. Dari keterampilan yang sering dilatih adalah menjahit sehingga hal ini dapat menjadi dasar adanya kesiapan dalam memulai usaha rintisan salon. Hal ini juga didukung pada keterampilan tata rias pada beberapa difabel dalam pementasan drama. Kedua keterampilan ini menjadi dasar yang cukup baik pada diri difabel.

Konselor membantu konseli akan penyelesaian masalah dalam diri. Namun dalam hal ini konselor perlu memperhatikan "as a counselor, it is your role to assist clients in clarifying their own values and in making their own decisions. Monitor yourself to be sure you are separating your values from the values of your clients" (Corey, 2010: 454). Perlu adanya nilai dalam diri konselor yang memahami akan perbedaan diri dengan konseli. Hal ini didukung empati yang tepat dalam Baron (2005: 291) "This is unselfish because it leads us 
to offer help for no extrinsic reason, but it is also selfish, in one sense, since the behavior of assisting others helps us, too: it can make us feel better". Empati sebagai konselor muncul dalam proses ini.

disebutkan dalam Australian Aid: Indonesia Infrastructure Initiative (2016) ada tiga kriteria yang penting bagi difabel yaitu salah satunya yaitu transportasi yang menunjang difabel untuk dapat beraktifitas khususnya dalam bekerja. Difabel yang memiliki mobilitas yang baik akan menjadi awal dari kinerja yang baik pula. Ladda (2012) menyatakan kondisi yang dialami di Thailand hampir sama dengan yang ada di Indonesia sekarang ini. Begitu cepatnya budaya asing yang masuk pada masyarakat lokal sangat mempengaruhi semua aspek kehidupan. Hal ini juga yang sangat berpengaruh bagi difabel dalam bekerja. Persaingan semakin besar sehingga membutuhkan suatu keterampilan untuk dapat bekerja dalam kehidupan.

\section{METODE}

Pengabdian kepada masyarakat ini dilakukan dalam rangka mengetahui bagaimana kesiapan kinerja difabel dalam rintisan usaha tata rias salon di Kabupaten Tegal. Peserta 10 orang anggota DSM dan LBK yang dipilih dari 20 kandidat peserta awal. Kinerja difabel terlihat pada saat observasi dan wawancara dilakukan responden difabel anggota DSM Kabupaten Tegal. Kinerja yang dapat terlihat antara lain pada:

Tabel 1. Metode pelaksanaan pengabdian kepada masyarakat

\begin{tabular}{|c|c|}
\hline Metode & Indikator \\
\hline Workshop & $\begin{array}{l}\text { Peserta } \quad \text { diberikan } \\
\text { workshop keterampilan } \\
\text { dalam dasar usaha salon } \\
\text { yaitu busana kebaya dan } \\
\text { tata rias }\end{array}$ \\
\hline Pelatihan & $\begin{array}{l}\text { Peserta secara intensif } \\
\text { diberikan pelatihan oleh } \\
\text { narasumber dan tim } \\
\text { pengabdian } \\
\text { masyarakat }\end{array}$ \\
\hline $\begin{array}{l}\text { Achievement } \\
\text { Motivation } \\
\text { Counseling }\end{array}$ & $\begin{array}{l}\text { Dalam setiap pertemuan } \\
\text { tentu saja ada sesi } \\
\text { konseling bagi peserta } \\
\text { untuk } \\
\text { meningkatkan kinerja }\end{array}$ \\
\hline
\end{tabular}

$$
\text { dalam merintis usaha }
$$

\section{HASIL DAN PEMBAHASAN}

Pengabdian kepada masyarakat ini dilakukan berdasarkan dari hasil penelitian terdahulu yaitu pada "Pemberdayaan Difabel dalam Pelaksanaan Program Kelompok Usaha Bersama (KUBE) di Desa Suruh, Kecamatan Tasikmadu, Kabupaten Karanganyar" yang menjelaskan bahwa adanya strategi dalam memberdayakan difabel dilakukan dengan pemberian modal usaha, pelatihan usaha, peningkatan keterampilan, bimbingan motivasi usaha dan pendampingan (Wijayanto, 2015:141).

Selain itu pada penelitian "IBM kepada Kelompok Difabel di SLB Dharma Wanita Jiwan dan SDLBN Karangrejo Wungu di Kabupaten Madiun melalui Pemanfaatan Limbah Plastik Refill Rumah Tangga menjadi Produk Handicraff Ramah Lingkungan untuk Menekan Limbah Plastik Rumah Tangga dan Menumbuhkan Lifeskill serta Kemandirian Kaum Difabel dalam Menghadapi Tantangan Hidup" menyatakan bahwa jenis pengambangan diri (lifeskill) yang akan diberikan adalah pelatihan tentang berbagai keterampilan yang bermanfaat bagi simber penghidupan kaum difabel secara mandiri.

Maka dengan adanya penelitian terdahulu mengenai pemberdayaan bagi difabel baik dalam keterampilan maupun lifeskill, hal ini yang mendasari adanya Program Kemitraan Masyarakat ini. Pengingkatan kinerja difabel pada usaha tata rias salon ini relevan dengan temuan di lapangan bahwa difabel ada yang memiliki keterampilan menjahit dan rias. Maka dengan hal tersebut bisa menjadi dasar adanya pelaksanaan pengabdian kepada masyarakat.

\section{Workshop}

Pada pelaksanaan Pengabdian kepada Masyarakat ini dilakukan kepada 10 peserta Program Kemitraaan Masyaraakat yang terdiri dari anggota DSM (Difabel Slawi Mandiri) dan LBK (Loka Bina Karya). Peserta kegiatan PKM "Achievement Motivation Counseling untuk Meningkatkan 
Kinerja Difabel dalam Usaha Tata Rias Salon di Kabupaten Tegal" mengikuti rangkaian kegiatan dari bulan Maret - November 2018 selama delapan bulan Program Kemitraan Masyarakat tahun 2018.

Kegiatan pertama yang dilakukan adalah workshop pada tanggal 22 April 2018 yang diselenggarakan sebagai dasar usaha tata rias salon bagi difabel yaitu pemberian materi mengenai motivasi dalam bekerja yang termasuk dalam Achievement Motivation Counseling. Pentingnya konseling bagi difabel dilakukan dalam rangka menguatkan kinerja yang selama ini dilakukan difabel yaitu pada usaha busana dan rias. Kemampuan difabel dalam bekerja sangat beragam, hal ini yang menjadi dasar dalam Pengabdian kepada Masyarakat ini yaitu sebagai dorongan kepada difabel melalui konseling. Selain dari konseling yang dilakukan juga melalui kinerja yang dilakukan difabel yaitu busana kebaya dan rias. Dua kegiatan dasar ini sebagai pembentuk dari usaha tata rias salon bagi difabel.

Workshop yang dilakukan kepada peserta PKM menggunakan materi konseling yang didampingi oleh narasumber dari busana kebaya dan tata rias. Pada workshop ini peserta memiliki kesempatan untuk memahami kondisi diri untuk melanjutkan dalam peluang usaha yang berdasarkan dari kemampuan dasar busana kebaya dan rias. Fokus dari penguatan ini dilakukan untuk dapat memberikan motivasi dalam bekerja bagi difabel baik dalam fokus busana kebaya dan rias.

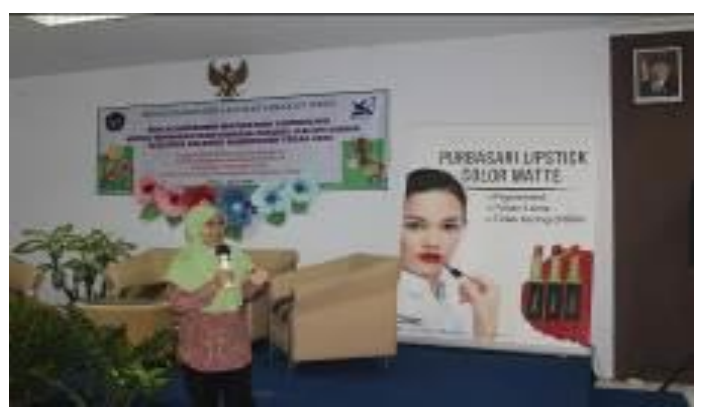

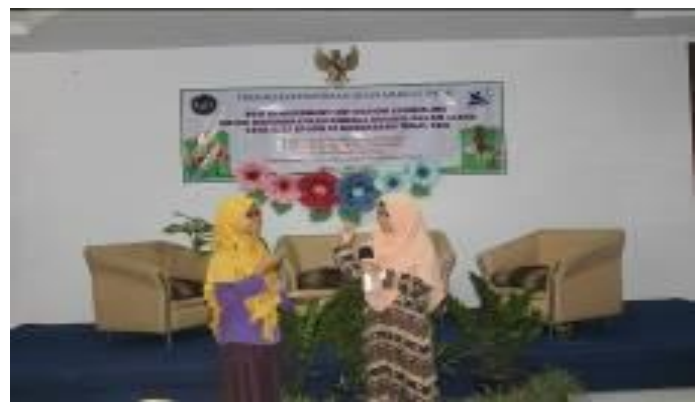

Gambar 1 dan 2: Tim pengabdian kepada masyarakat memberikan materi Achievement Motivation Counseling kepada peserta difabel

\section{Pelatihan Busana Kebaya}

Pelatihan yang dilakukan pada PKM "Achievement Motivation Counseling untuk Meningkatkan Kinerja Difabel dalam Usaha Tata Rias Salon di Kabupaten Tegal" terdiri dari kegiatan busana kebaya dan tata rias. Pelatihan yang dilakukan pertama adalah dalam busana kebaya. Pentingnya dalam pemilihan busana kebaya pada usaha tata rias salon adalah untuk memberikan peluang usaha kepada difabel dalam membuat dan menyewakan kebaya. Pelatihan busana kebaya yang dilakukan peserta terdiri dari awal pembuatan sampai pada tahap penyelesaian busana kebaya.

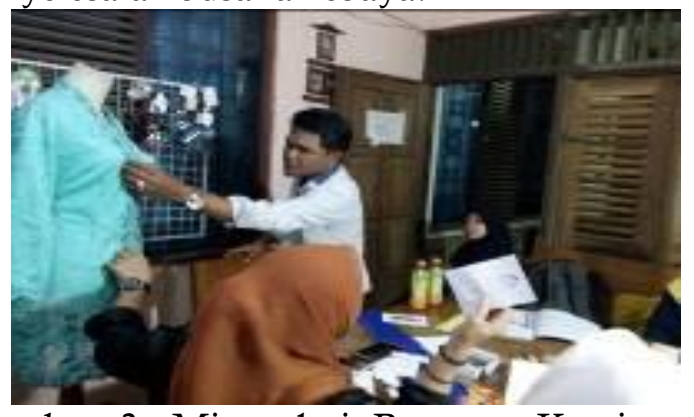

Gambar 3. Mitra dari Program Kemitraan Masyarakat mengikuti pelatihan busana kebaya

Selama pelatihan ini Tim Program Kemitraan Masyarakat memberikan pendampingan berupa Achievement Motivation Counseling kepada difabel dalam usaha dan motivasinya dalam mengikuti semua rangkaian kegiatan pelatihan busana kebaya. Dalam proses pembuatan busana kebaya dapat dicermati dalam tahapan berikut ini. Achievement Motivation Counseling yang dilakukan terintegrasi dalam proses pelatihan bagi difabel. Hal yang perlu diperhatikan bahwa, usaha tidak akan mengkhianati hasil. Usaha dari dalam diri difabel mencerminkan usaha dalam merintis usaha tata rias salon 
difabel. Pada tahapan pelatihan busana kebaya antara lain.

1) Persiapan Pola Kebaya

Pada tahap pertama merupakan dasar dari cara pembuatan busana kebaya. $\mathrm{Hal}$ yang sangat menarik bahwa kebaya adalah model busana yang tidak sama dengan baju pada umumnya. Kebaya adalah busana yang memiliki pola seni yang sedemikian cantik sehingga dalam pembuatannya pula memerlukan teknik dan cara khusus. Pada tahap pelatihan ini konseling yang dilakukan adalah tahap membangun hubungan dalam konseling yaitu memulai konseling pada difabel. Hubungan yang baik antara Tim Program Kemitraan Masyarakat dengan para peserta sangat dibutuhkan sebagai dasar komitmen untuk membangun usaha tata rias salon. Kesempatan ini dilakukan pada tahap pelatihan persiapan pola kebaya.

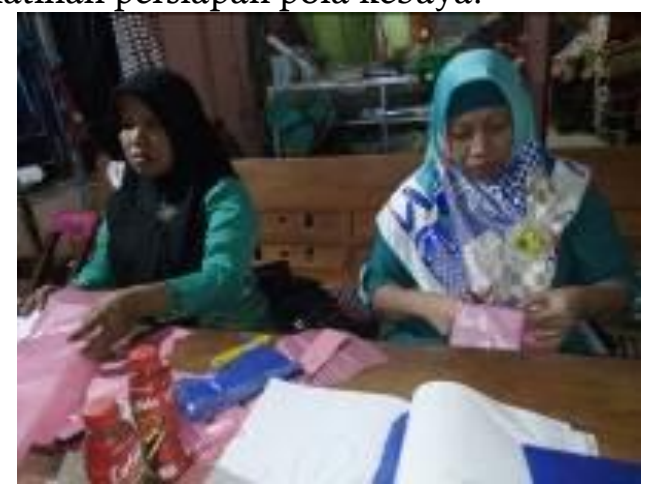

Gambar 4. Pembuatan pola kebaya oleh mitra difabel

\section{2) Pembuatan Pola Kebaya}

Pola merupakan cetak biru dalam tata busana. Maka dari itu pola yang diukur harus presisi seusai dengan perhitungan yang tepat. Pembuatan pola kebaya ini terdiri dari lima macam kebaya yaitu (1) kebaya layer, (2) kebaya tanpa layer, (3) kebaya kartini, (4) kebaya pasundan dan (5) kebaya plum. Pada tahap pelatihan ini konseling yang digunakan adalah tahap mengubah persepsi dalam konseling yaitu dengan mengkomunikasikan kepada difabel akan realita pada pentingya pada usaha dilakukan saat ini. Realita yang dihadapi adalah sebagian besar orang akan memberikan kepercayaan pada hasil jahitan khususnya kebaya yang sesuai dengan pesanan. Keterampilan ini yang hanya sebagian penjahit miliki untuk dapat membuat busana kebaya yang pas dan nyaman dipakai. Dasar dari penilaian tersebut yang membuat difabel sadar akan realita akan pentingnya usaha tata rias salon salah satunya adalah pemenuhan pasar pelanggan akan busana kebaya.

3) Pencetakan Pola Kebaya pada Kain Lace

Kain yang digunakan sebagai busana kebaya adalah kain lace atau biasa disebut brokat. Pemilihan kain juga menjadi hal penting bagi kenyamanan pemakai. Kain lace memiliki motif yang beragam dan nyaman digunakan pada kondisi cuaca di Indonesia. Kain lace yang digunakan dalam busana kebaya ini terdiri dari lima warna yang berbeda sesuai dengan tipe kebaya yang dibuat. Warna-warna tersebut antara lain (1) merah maroon untuk kebaya layer, (2) cream muda untuk kebaya tanpa layer, (3) hijau lembayung untuk kebaya kartini, (4) biru dongker untuk kebaya pasundan dan (5) ungu tua untuk kebaya plum.

Pada pencetakan pola ke kain lace yang sangat perlu diperhatikan adalah keakuratan pola yang telah dibuat. Pada tahapan pemotongan kain lace merupakan saat yang krusial. Sedikit saja kesalahan dalam memotong kain, maka dapat berakibat kain tidak dapat digunakan lagi untuk dijahit dalam bentuk busana utuh. Proses konseling yang dilakukan pada pelatihan ini adalah tahap mengarahkan dalam konseling yaitu memberikan arahan kepada difabel demi kepentingan usaha dari difabel. Difabel menanggapi dari arahan Tim Program Kemitraan Masyarakat yang memberikan Achievement Motivation Counseling dengan berbagai tanggapan seperti penerimaan, klarifikasi, pernyataan ulang bahkan interpertasi. Semuanya terjadi dalam proses konseling yang dilakukan dari Tim Kemitraan Masyarakat selama mendampingi difabel dalam pelatihan.

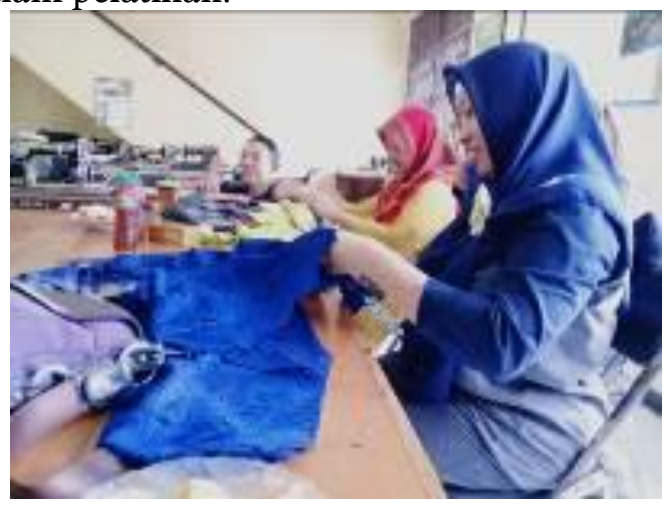


Gambar 5. Pembuatan busana kebaya oleh mitra difabel pada tahap menjahit kain lace

4) Menjahit Kain Lace

Proses menjahit kain lace membutuhkan fokus yang baik. Menjahit kebaya seperti menjahit kain pada umumnya. Namun di sini perlu dilihat cetak biru yang sudah dipotong sesuai pola. Kemudian dilanjutkan dijahit sesuai dengan pola kebaya masing-masing. Tahap menanggapi dengan multi fokus dalam konseling yaitu perlu memberikan tanggapan dari difabel sejalan dengan materi pelatihan yang semakin detail. Difabel seperti kita pada umumnya memiliki cara tersendiri dalam memproses informasi. Khususnya selama proses pelatihan busana kebaya banyak hal yang difabel pelajari. Berbagai informasi masuk ke dalam diri difabel yang ditanggapi difabel dalam semua inderanya. Ketidaklengkapan tubuh tidak menghalangi difabel untuk menerima informasi.

Konselor yaitu Tim Program Kemitraan Masyarakat memberikan tanggapan multi fokus dalam bahasa yang ditangkap sebagai perasan difabel, perilaku optimis dan keniatan dalam berusaha. Penggunaan kata sangat penting dalam menanggapi multi fokus ini. Jangan sampai menggunakan pilihan kata dan kalimat yang memberikan dampak negatif bagi usaha difabel.

\section{5) Merapikan Jahitan Kain Lace}

Dalam menjahit kain lace ini sudah merupakan bentukan dari busana kebaya awal. Busana kebaya hampir dapat terlihat bentuknya. Proses menjahit kain lace menggunakan jarum jahit nomor 13. Kesesuaian jarum jahit penting karena kain lace ini memiliki kerapatan yang renggang sehingga diperlukan jarum yang menghubungan benang secara pas ke dalam kain. Proses konseling yang dilakukan pada tahap merapikan jahitan kain lace adalah tahap empati yang akurat dalam konseling yaitu mengklarifkasikan masalah dalam diri difabel selama mengikuti pelatihan yang dimaksudkan sebagai motivasi dalam usaha.

Perilaku difabel yang mengikuti kegiatan pelatihan pada Program Kemitraan Masyarakat ini sejalan dengan berbagai hal yang dirasakan difabel. Empati yang akurat untuk memahami difabel dalam rintisan usaha tata rias salon ini antara lain memahami bahwa difabel memiliki dasar keterampilan yang baik, namun belum dapat optimal dilakukan. Difabel merasa bahwa keterampilan menjahit sebagai dasar usaha tata rias salon pembuatan dan penyewaan kebaya dilihat sebagai peluang yang bagus untuk diri difabel. Peluang ini ditindaklanjuti oleh difabel yang sudah mendapatkan apresiasi dalam hasil kerjanya.

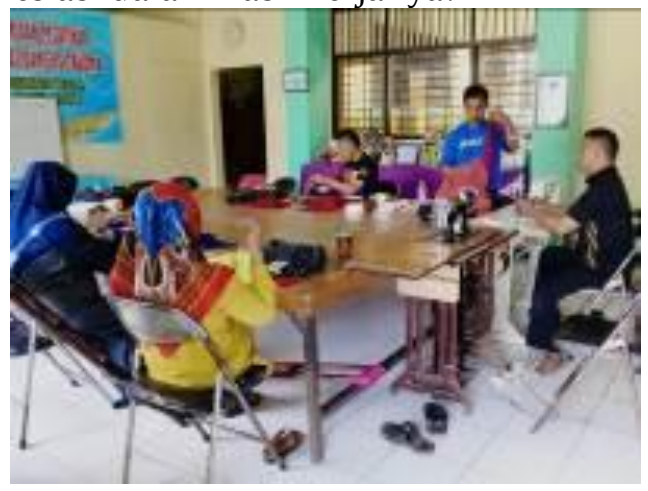

Gambar 6. Pembuatan busana kebaya oleh mitra difabel

6) Aplikasi Aksesoris pada Kebaya

Tahap terakhir dari busana kebaya ini adalah finishing aplikasi manik-manik, bordir dan payet. Kebaya yang sudah jadi di fitting pada model yang kemudian akan ditambahkan aplikasi pada kebaya. Hal ini dilakukan untuk melihat pas tidaknya kebaya yang telah dijahit. Konseling yang dilakukan pada tahap ini adalah tahap pengungkapan diri dalam konseling yaitu dilakukan difabel selama mengikuti seluruh rangkaian pelatihan busana kebaya secara sadar akan pentingnya suatu usaha tersebut. Pengungkapan diri difabel berarti bahwa difabel menyadari kelebihan dan kekurangannya yang dapat menjadi informasi yang diketahui oleh orang lain. Bagi difabel pengungkapan diri ini sebagai cara untuk dapat memberikan kepercayaan bagi orang lain akan usahanya.

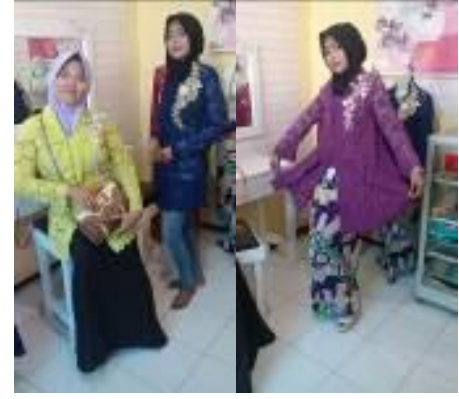


Gambar 7. Hasil busana kebaya dari karya mitra difabel DSM dan LBK yang dipakai oleh mitra difabel di lokasi salon Program Kemitraan Masyarakat

\section{Tata Rias}

Tim

\section{Program}

Kemitraan

Masyarakat memberikan

Achievement

Motivation Counseling untuk membantu difabel membangun rasa percaya dan memfasilitasi hubungan konseling. Rasa percaya difabel akan keterampilan busana kebaya sebagai salah satu elemen dalam usaha tata rias salon sangat berarti bagi keberlangsungan usaha tersebut. Kesulitan, tantangan dan stigma negatif diri difabel dapat perlahan dihilangkan dengan kemauan difabel untuk mengakui diri.

Palatihan kedua adalah tata rias bagi difabel yaitu elemen kedua dalam rintisan usaha tata rias salon difabel. Tata rias ini adalah dasar dari usaha tata rias salon dari segi keterampilan dalam kecantikan. Beberapa jenis keterampilan ini diperoleh dari narasumber dan Tim Program Kemitraan yang memiliki keterampilan yang dapat dipelajari difabel.

1) Rias wajah (make up)

Pada tahap pertama keterampilan tata rias adalah rias wajah atau make up. Difabel yang memiliki keterampilan dasar dalam merias wajah diperdalam dalam pelatihan ini. Pendampingan kepada difabel dilakukan untuk mempelajari lebih lanjut mengenai berbagai macam tipe riasan wajah. Pada pelatihan rias wajah ini difabel masih dapat menggunakan anggota gerak untuk dapat mengaplikasikan riasan pada wajah. Aplikasi riasan memiliki cara dan trik tersendiri untuk mendapatkan hasil riasan yang lebih terlihat memukau. Hal ini yang dipelajari difabel kerena berbeda dengan rias wajah yang sehari-hari dilakukan.

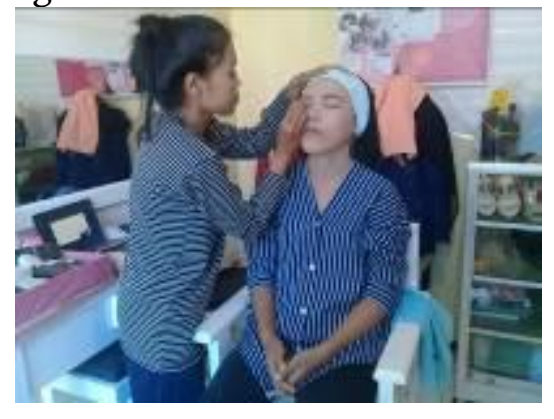

Gambar 8. Mitra difabel yang sedang melakukan tata rias di salon Program Kemitraan Masyarakat

Konseling yang dilakukan

Achievement Motivation Counseling pada tahap tata rias wajah adalah tahap kontrak dalam konseling yaitu berfokus pada proses yang terlibat dalam pencapaian usaha tata rias salon difabel dan hasil akhir. Sangat penting bagi difabel untuk menetapkan kontrak pada dirinya maupun pada komitmen usaha yang akan dijalani yaitu usaha tata rias salon. Tim Program Kemitraan Masyarakat telah menyiapkan alat dan bahan rias wajah yang bisa digunakan oleh difabel untuk mejalankan usaha tata rias salon. Difabel berlatih tata rias dilakukan pada jadwal yang telah disepakati oleh para peserta difabel. Hal ini merupakan tindak lanjut dari kontrak yang telah disepakati oleh peserta Program Kemitraan Masyarakat.

Tata rias wajah dilakukan melalui beberapa tahapan keterampilan, antara lain pengenalan bentuk wajah, hati-hati area berminyak, membersihkan wajah, pelembab, alas bedak, shading \& highlight, shading hidung, face powder, triple action cake, eyebrow pencil, eye shadow, eyeliner pen, mascara, eyeliner pencil, blush on, lipstick, lipgloss, lip balm. Dari rangkaian kegiatan tersebut dilakukan difabel dalam kegiatan latihan yang sudah disepakati oleh peserta Program Kemitraan Masyarakat.

2) Potong rambut oval

Pada pelatihan potong rambut oval dilakukan oleh Tim Program Kemitraan Masyarakat bersama narasumber. Hal ini dilakukan dalam rangka meningkatkan performa dari keterampilan difabel yang sudah bagus dalam tata rias. Usaha tata rias salon salah satu unsurnya adalah potong rambut. Keterampilan potong rambut sangat dicari oleh masyarakat khususnya yang berada di sekitar kantor Loka Bina Karya Difabel Slawi Mandiri. Pada kantor tersebut banyak dari difabel dan masyarakat umum yang menjadi pasar potensial bagi berkembangnya usaha tata rias salon difabel.

Pada pelatihan potong rambut oval ini konseling dilakukan pada tahap latihan (reherseal) dalam konseling yaitu memaksimalkan peluang usaha tata rias salon melalui latihan setelah kontrak ditetapkan. Difabel yang telah mendapatkan pelatihan 
akan melanjutkan latihan tersebut dalam tugas rumah. Seperti latihan potong rambut oval maka dapat menjadi bahan belajar untuk dipaham lebih lanjut saat di rumah. Rambut yang sebelum dipotong dan sesudah dapat menjadi referensi dalam pengalaman difabel untuk memotong rambut selanjutnya.

\section{3) Potong rambut trap}

Selain potong rambut oval, pelatihan potong rambut trap perlu dilakukan karena menjadi kebutuhan pasar yang potensial. Pelatihan potong rambut trap dilakukan oleh Tim Program Kemitraan Masyarakat bersama narasumber kepada difabel yang telah berlatih sebelumnya. Pengalaman dari difabel untuk memotong rambut. Pada keterampilan dasar yang dimiliki difabel yaitu memotong rambut dalam cara sederhana, belum mendapatkan cara khusus dalam memotong rambut. Dengan adanya pelatihan potong rambut ini, difabel dapat lebih mengetahui cara secara teori dan praktek dalam memotong rambut.

Konseling yang dilakukan pada pelatihan potong rambut trap ini adalah tahap pengungkapan diri dalam konseling yaitu mengajak difabel untuk membicarakan topik peluang usaha tata rias salon. Pengungkapan diri ini dibutuhkan oleh difabel untuk melihat tantangan dan peluang usaha dari keterampilan yang dimiliki pada tata rias salon. Hambatan yang dirasakan dalam diri difabel terutama diungkapkan dalam proses konseling. Hal ini yang dapat menjadi peluang bagi difabel untuk bisa berusaha yang didasarkan pada kemauan diri untuk maju.

4) Keramas rambut

Selain dari latihan potong rambut, maka yang tidak kalah penting adalah latihan keramas rambut. Masyarakat yang terbiasa untuk ke salon maka tidak asing untuk melakukan keramas sebelum aktivitas potong rambut, creambath, masker rambut dan catok. Hal ini menjadi dasar dalam usaha tata rias salon untuk dapat memberikan jasa keramas rambut yang menambah nilai jual kepada masyarakat. Keramas rambut yang dilakukan pada usaha tata rias salon Program Kemitraan Masyarakat ini dilakukan kepada masyarakat baik laki-laki maupun perempuan.

Konseling yang dilakukan yaitu pada pelatihan keramas rambut adalah tahap imediasi dalam konseling yaitu keberanian dan ketegasan dalam diri difabel untuk memasuki usaha tata rias salon. Perlunya keberanian dalam difabel untuk menjalankan peluang usaha tata rias salon ini sangat tergantung pada diri difabel sendiri. Pelatihan dasar usaha tata rias salon telah dipelajari oleh difabel peserta Program Kemitraan Masyarakat yaitu busana kebaya dan tata rias. Hal ini menjadi kunci dasar bagi ketegasan diri difabel untuk menjalankan usaha yang telah dirintis bersama ini.

5) Pijat kepala

Tahap selanjutnya dalam tata rias ini adalah pijat kepala. Pada pelatihan pijat kepala dilakukan oleh difabel yang memiliki keterampilan dalam memijat. Difabel yang telah memiliki keterampilan dalam pijat kepala dilatih dalam usaha tata rias salon untuk dapat menjadi bagian yang utuh dalam usaha tata rias salon difabel. Keterampilan pijat kepala sangat disukai oleh masyarakat yang berada di salon untuk memberikan hasil yang memuaskan.

Konseling yang dilakukan pada pelatiha pijat kepala ini yaitu pada tahap humor dalam konseling yaitu untuk memberikan daya pikir yang kreatif bagi difabel untuk memberikan jasa yang baik kepada orang lain. Dalam usaha tata rias salon sangat membutuhkan interaksi yang baik dari difabel kepada konsumen yang datang. Dengan pelayanan yang baik dari difabel yaitu daya pikir kreatif untuk mengembangkan usaha tata rias salon. Dengan komunikasi dan pelayanan jasa yang baik kepada masyarakat sangat membuka peluang bagi difabel untuk dapat memasarkan usaha tata rias salon ini dari pengalaman jasa usaha tata rias salon difabel.

Daya pikir kreatif ini yang menjadi inti dari kelanjutan usaha tata rias salon yang telah dirintis dari Program Kemitraan Masyarakat. Daya keatifitas difabel untuk memberikan pelayanan yang baik tentu saja disertai humor dan persuasi yang baik untuk menarik minat kepada masyarakat. Dalam komunikasi dan interkasi kepada masyarakat ini yang akan membawa informasi mengenai adanya usaha tata rias salon kepada khalayak masyarakat. 


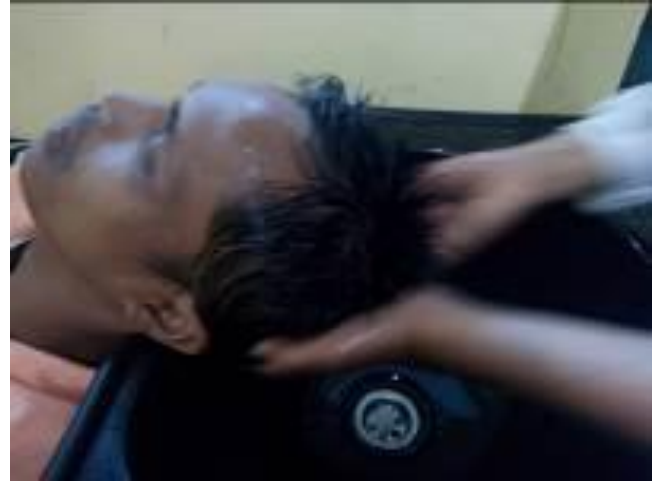

Gambar 10. Pijat kepala yang dilakukan di salon Program Kemitraan Masyarakat

6) Catok rambut

Pangsa pasar yang sangat diminati masyarakat adalah catok rambut. Hal ini yang menjadi dasar bagi Tim Program Kemitraan Masyarakat untuk memberikan pelatihan catok rambut kepada difabel. Pada usaha tata rias salon difabel Program Kemitraan Masyarakat memiliki keuntungan berada di dalam kantor Loka Bina Karya - Difabel Slawi Mandiri Kabupaten Tegal. Informasi dari pegawai yang beraktivitas di kantor dapat mencatok rambut di usaha tata rias salon difabel.

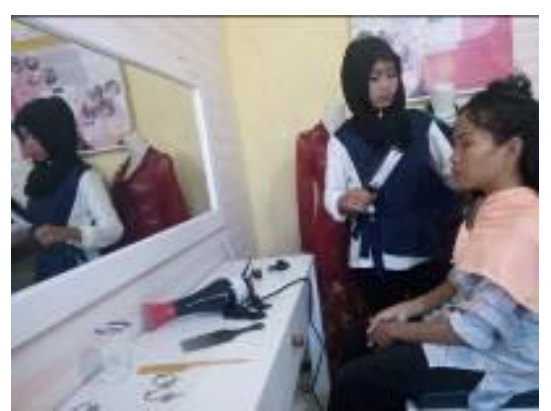

Gambar 11. Proses catok rambut yang dilakukan oleh mitra difabel sebagai bentuk keterampilan usaha tata rias salon

Konseling yang dilakukan pada latihan catok rambut ini pada tahap empati yang akurat dalam konseling yaitu ekspresi dari difabel sebagai kesiapan untuk menjalankan usaha tata rias salon. Empati dilakukan dari konselor (Tim Program Kemitraan Masyarakat) kepada peserta difabel Program Kemitraan Masyarakat untuk memahami kondisi yang ada dalam diri difabel. Empati dilakukan dengan melibatkan komunikasi akan pemahaman dasar tentang apa yang dirasakan difabel selama mengikuti kegiatan Program Kemitraan Masyarakat. Sangat perlu adanya keterlibatan dari dalam diri difabel peserta Program Kemitraan Masyarakat untuk menjalankan usaha tata rias salon. Untuk membangun hubungan yang berkesinambungan ini diperlukan komitmen dari segenap peserta Program Kemitraan Masyarakat untuk dapat membangun diri difabel melalui kinerja dalam usaha tata rias salon difabel.

\section{ACKNOWLEDGEMENT}

Pengabdian kepada Masyarakat ini didanai oleh DRPM Risetdikti melalui Hibah Program Kemitraan Masyarakat (PKM) Tahun Anggaran 2018.

\section{SIMPULAN DAN SARAN}

Dengan keseluruhan pelatihan yang didapatkan oleh peserta difabel Program Kemitraan Masyarakat dati mitra Loka Bina Karya dan Difabel Slawi Mandiri diharapkan dapat menjadi peluang usaha tata rias salon yang dibentuk dari keterampilan busana kebaya dan tata rias. Keberlanjutan dari keterampilan difabel sudah ditindaklanjuti dengan adanya Program Kemitraan Masyarakat "Achievement Motivation Counseling untuk Meningkatkan Kinerja Difabel dalam Usaha Tata Rias Salon di Kabupaten Tegal" yang didanai oleh DRPM Risetdikti tahun 2018.

Program Kemitraan Masyarakat ini masih dalam proses penyelenggaraanya. Keseluruhan kegiatan tidak lepas dari peran serta berbagai pihak. Keberlanjutan dari kegiatan ini sangat diharapkan oleh pihak pengabdian maupun dari mitra, sehingga akan ada rencana tahapan berikutnya. Akhir dari Program Kemitraan Masyarakat tahun 2018 bukan menjadi akhir dari jalinan dengan mitra. Akan ada tahapan berikutnya untuk dapat memberikan kontribusi yang bermanfaat bagi mitra.

Konseling yang telah dilakukan kepada mitra difabel sangat berdampak pada kesehariannya. Dukungan dari berbagai pihak menjadikan diri difabel dapat semakin berkembang. Kemampuan difabel dalam memahami diri khususnya dalam kinerjanya dapat dilakukan dengan optimal. Kinerja yang ditunjukkan dalam mempersiapkan 
usaha tata rias salon dirintis dari kemampuan difabel dalam bidang tata rias dan tata busana. Dukungan untuk mengembangkan keterampilan tata rias dan tata busana sangat disambut baik oleh mitra difabel. Maka untuk kedepannya akan dilaksanakan pengabdian kepada masyarakat dalam Program Kemitraan Masyarakat bagi difabel untuk dapat mendalami lagi keterampilan tersebut.

\section{DAFTAR RUJUKAN}

Australian Aid. 2016. Briefing Note Indonesia Infrastructure Initiative.

Baron, Robert A \& Donn Byrne. 2005. Psikologi Sosial edisi 10. Alih bahasa Ratna Djuwita (dkk). Jakarta: Erlangga.

BPS Kabupaten Tegal. 2015. Pemerintah Kabupaten Tegal.

Corey, Gerald \& Marianne Schneider Corey. 2010. I Never Knew I Had a Choice $9^{\text {th }}$. USA: Brooks/Cole.

Cornish, Jennifer A. Ericson et all. 2010. Handbook of Multicultural Counseling Competencies. New Jersey: John Wiley \& Sons, Inc.

Covey, Stephen R. 2015. The Seven Habits of Highly Effevtive People (7 Kebiasaan Manusia yang Sangat Efektif). Jakarta: PT Dunamis Intra Sarana.

International Labour Organization. 2015. Inklusi Penyandang Disabilitas Muda: Kasus Bisnis. Organisasi Perburuhan Internasional: Jakarta.

Ladda, Silanoi. 2012. The Development of Teaching Pattern for Promoting the Building Up of Character Education Based on Sufficiency Economy Philosophy in Thailand. ProcediaSocial and Behavioral Sciences 69 (2012) 1812-1816.

Ningsih, Nuri Ati dan Asri Musandi Waraulia. 2015. IBM kepada Kelompok Difabel di SLB Dharma Wanita Jiwan dan SDLBN
Karangrejo Wungu di Kabupaten Madiun melalui Pemanfaatan Limbah Plastik Refill Rumah Tangga menjadi Produk Handicraff Ramah Lingkungan untuk Menekan Limbah Plastik Rumah Tangga dan Menumbuhkan Lifeskill serta Kemandirian Kaum Difabel dalam Menghadapi Tantangan Hidup. Seminar Nasional Universitas PGRI Yogyakarta.

PP Nomor 43 tahun 1998 tentang Upaya Peningkatan Kesejahteraan Sosial Penyandang Cacat

Pineida, Felipe Oyarzo. (2011). Competencies for the 21st Century: Integrating ICT to Life, School and Economical Development. Procedia - Social and Behavioral Sciences. (28): $54-57$.

Sugiono dkk. 2014. Indonesian Journal of Disability Studies. Klasterisasi Mahasiswa Difabel Indonesia berdasarkan Backgruound Histories dan Studying Performance. Volume 1 Issues 1 pp 20-26.

Undang-undang Nomor 8 Tahun 2016 Tentang Penyandang Disabilitas diunduh pada https://www.bphn.go.id/data/docu ments/98pp043.pdf

Wijayanto, Hendra. 2015. IJPA-The Indonesian Journal of Public Administration. Pemberdayaan Difabel dalam Pelaksanaan Program Kelompok Usaha Bersama (KUBE) di Desa Suruh, Kecamatan Tasikmadu, Kabupaten Karanganyar. Volume 1 Nomor 2 page 138-160. 